Supporting Information

\title{
Bioactivation of Heterocyclic Aromatic Amines by UDP
}

\section{Glucuronosyltransferases}

Tingting Cai, Lihua Yao, Robert J. Turesky*

Masonic Cancer Center and Department of Medicinal Chemistry, University of Minnesota,

Minneapolis, MN 55455

*Corresponding author 
Table S-1. Steady-state enzyme kinetic parameters for glucuronidation of HONH-A $\alpha \mathrm{C}$ by recombinant UGT isoforms. S-3

Table S-2. The accurate mass measurements of Gluc conjugates of HONH-A $\alpha \mathrm{C}$ and their product ions. S-4

Table S-3. The intra-day and inter-day reproducibility of the quantitative analysis of UGT peptides in liver microsomes.

Table S-4. The accurate mass measurements of Gluc conjugates of HONH-PhIP and their product ions. S-6

Table S-5. P450 Ethoxyresorufrin-O-deethylase (EROD) activities in human kidney and liver microsomes. S-8

Figure S-1. The high resolution mass spectra of Gluc conjugates of HONH-A $\alpha \mathrm{C}$ in (A) negative ion mode and (B) positive ion mode.

Figure S-2. A representative UPLC-ESI/MS ${ }^{2}$ and UPLC-ESI/MS ${ }^{3}$ chromatograms of Gluc metabolites of $\mathrm{HONH}-\mathrm{A} \alpha \mathrm{C}$ in human microsomes. A) HONH-A $\alpha \mathrm{C}-\mathrm{Gluc}$ metabolites formed with liver microsomes; B) The mass spectra of $\mathrm{HONH}-\mathrm{A} \alpha \mathrm{C}-\mathrm{Gluc}$ metabolites; C) Freshly prepared calibration curves of HONH-A $\alpha$ C-Gluc metabolites spiked into human liver microsomes $(0,0.005,0.01,0.02,0.05$, $0.1 \mu \mathrm{M})$. S-10

Figure S-3. The rates of formation of $\mathrm{HONH}-\mathrm{A} \alpha \mathrm{C}-\mathrm{Gluc}$ conjugates as a function of time with human kidney microsomes (HKM) and human liver microsomes (HLM). A) The rates of $\mathrm{A} \alpha \mathrm{C}-\mathrm{HN}^{2}-O-\mathrm{Gluc}$ formation; B) The rates of $\mathrm{A} \alpha \mathrm{C}-\mathrm{HON}{ }^{2}$-Gluc formation. S-11

Figure S-4. The UPLC-ESI/MS ${ }^{3}$ chromatograms and mass spectra of unlabeled and labeled peptides of UGT1A1 and UGT1A9. S-12

Figure S-5. Optimization of trypsin digestion. A) Calibration curves of UGT peptides (unlabeled peptides spiked into mouse liver microsomes with 1 pmol labeled peptides internal standards); B) Kinetics of UGT digestion with trypsin and recovery of $\mathrm{T}^{78} \mathrm{YPVPFQR}^{85}$ and $\mathrm{A}^{92} \mathrm{FAHAQWK}{ }^{99}$; ) Comparison of different trypsin to protein ratios and recovery of peptides $\mathrm{T}^{78} \mathrm{YPVPFQR}^{85}$ and $\mathrm{A}^{92}$ FAHAQWK $^{99}$. S-13

Figure S-6. The correlation between UGT1A1 and UGT1A9 protein expression levels in human liver microsomes. S-14

Figure S-7. The stability of HONH-PhIP and its Gluc conjugates as a function of $\mathrm{pH}$. S-15 
Table S-1. Steady-state enzyme kinetic parameters for glucuronidation of HONH-A $\alpha \mathrm{C}$ by recombinant UGT isoforms. ${ }^{\mathrm{a}}$

\begin{tabular}{|c|c|c|c|c|c|}
\hline Substrate & Glucuronide & $\begin{array}{c}\text { UGT } \\
\text { Isoform }^{b}\end{array}$ & $\begin{array}{c}V_{\max } \\
\text { pmol'min }^{-1} \cdot \mathrm{mg}^{-1} \text { protein }\end{array}$ & $\begin{array}{l}K_{\mathrm{m}} \\
\mu M\end{array}$ & $\begin{array}{c}V_{\max } / K_{\mathrm{m}} \\
\mu \mathrm{L} \cdot \mathrm{min}^{-1} \cdot \mathrm{mg}^{-1} \text { protein }\end{array}$ \\
\hline \multirow{7}{*}{$\mathrm{HONH}-\mathrm{A} \alpha \mathrm{C}$} & \multirow{4}{*}{$\mathrm{A} \alpha \mathrm{C}-\mathrm{HO} N^{2}$-Gluc } & UGT1A1 & $248 \pm 14.5$ & $49.8 \pm 7.9$ & 4.99 \\
\hline & & $\mathrm{UGT} 1 \mathrm{~A} 4^{\mathrm{c}}$ & $3960 \pm 606$ & $1140 \pm 227$ & 3.48 \\
\hline & & UGT1A9 & $15.0 \pm 1.8$ & $6.3 \pm 4.5$ & 2.37 \\
\hline & & UGT2B7 & $447 \pm 60.9$ & $173 \pm 43.2$ & 2.58 \\
\hline & \multirow{3}{*}{$\mathrm{A} \alpha \mathrm{C}-\mathrm{H} N^{2}-O$-Gluc } & UGT1A1 & $575 \pm 33.7$ & $21.4 \pm 4.4$ & 26.9 \\
\hline & & UGT1A $9^{\mathrm{d}}$ & $57.5 \pm 3.5$ & $0.7 \pm 0.6$ & 77.1 \\
\hline & & UGT2B7 & $60.5 \pm 5.9$ & $78.4 \pm 18.5$ & 0.77 \\
\hline
\end{tabular}

\footnotetext{
${ }^{a}$ Data obtained from reference. ${ }^{1}$
}

${ }^{\mathrm{b}}$ The glucuronidation activity (unit: $\mathrm{pmol}^{-} \mathrm{min}^{-1} \mathrm{mg}^{-1}$ microsomal protein) was examined for all UGT There was no detectable glucuronidation activity for $\mathrm{HONH}-\mathrm{A} \alpha \mathrm{C}$ with UGTs 1A3, 1A6 and 1A10. UGT1A8 displayed low glucuronidation activity of $\mathrm{HONH}-\mathrm{A} \alpha \mathrm{C}\left(<7 \mathrm{pmol}^{-\mathrm{min}^{-1}} \mathrm{mg}^{-1}\right.$ microsomal protein $)$.

${ }^{c}$ Kinetic constants could not be determined with confidence because of the high substrate concentrations required for analysis

${ }^{\mathrm{d}}$ Substrate inhibition was observed, $K_{\mathrm{si}}=255 \pm 58 \mu \mathrm{M}$. 
Table S-2. The accurate mass measurements of Gluc conjugates of HONH-A $\alpha \mathrm{C}$ and their product ions.

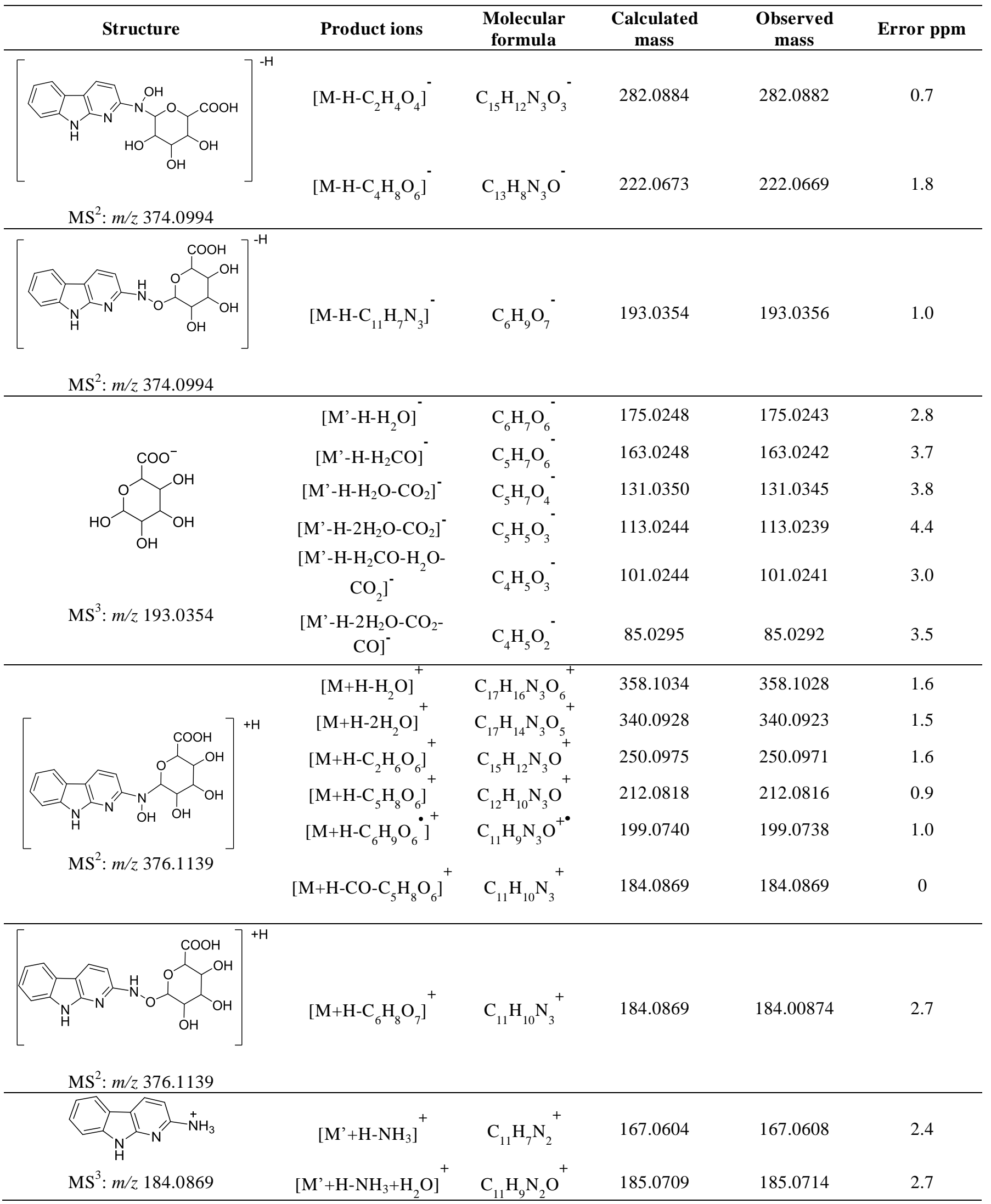


Table S-3. The intra-day and inter-day reproducibility of the quantitative analysis of UGT peptides in liver microsomes.

\begin{tabular}{cccccc}
\hline Peptides & $\begin{array}{c}\text { Median } \\
\text { (pmol/mg protein) }\end{array}$ & $\begin{array}{c}\text { Intra-day } \\
\mathbf{\%} \mathbf{C V}\end{array}$ & $\begin{array}{c}\text { Intra-day } \\
\mathbf{\%} \mathbf{C V}\end{array}$ & $\begin{array}{c}\mathbf{L O Q}^{\mathbf{a}} \\
\text { (pmol/mg protein) }\end{array}$ & $\begin{array}{c}\mathbf{L O D}^{\mathbf{b}} \\
\text { (pmol/mg protein) }\end{array}$ \\
\hline $\begin{array}{c}\text { UGT1A9/ } \\
\text { AFAHAQWK }\end{array}$ & 23.86 & 10.8 & 17.7 & 5 & 1 \\
$\begin{array}{c}\text { UGT1A1/ } \\
\text { TYPVPFQR }\end{array}$ & 52.60 & 8.3 & 17.1 & 5 & 1 \\
\hline
\end{tabular}

${ }^{a} \mathrm{LOQ}$, limit of quantification was obtained based on $\mathrm{S} / \mathrm{N}>10$.

${ }^{\mathrm{b}} \mathrm{LOD}$, limit of qualification was obtained based on $\mathrm{S} / \mathrm{N}>3$. 
Table S-4. The accurate mass measurements of Gluc conjugates of HONH-PhIP and their product ions.

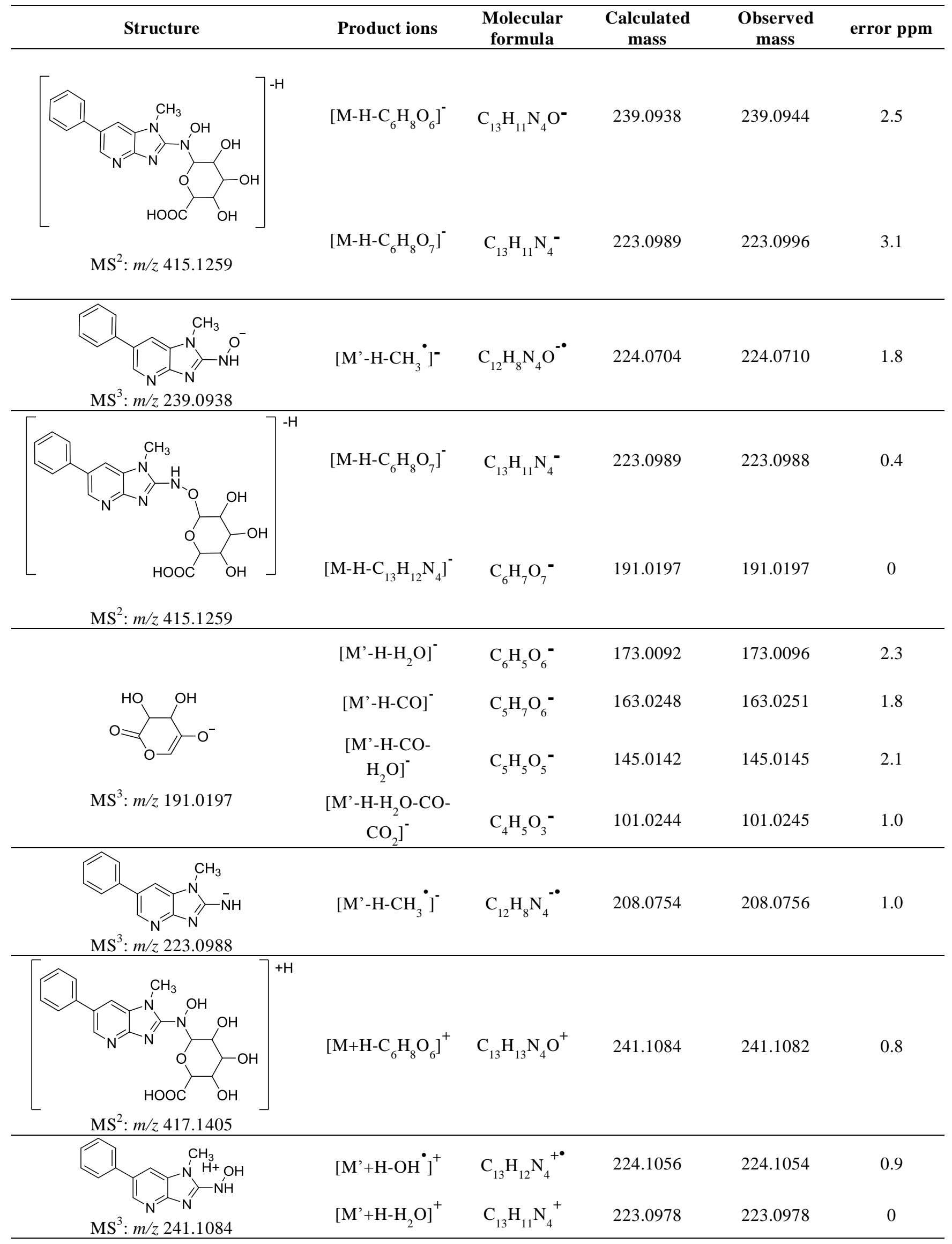




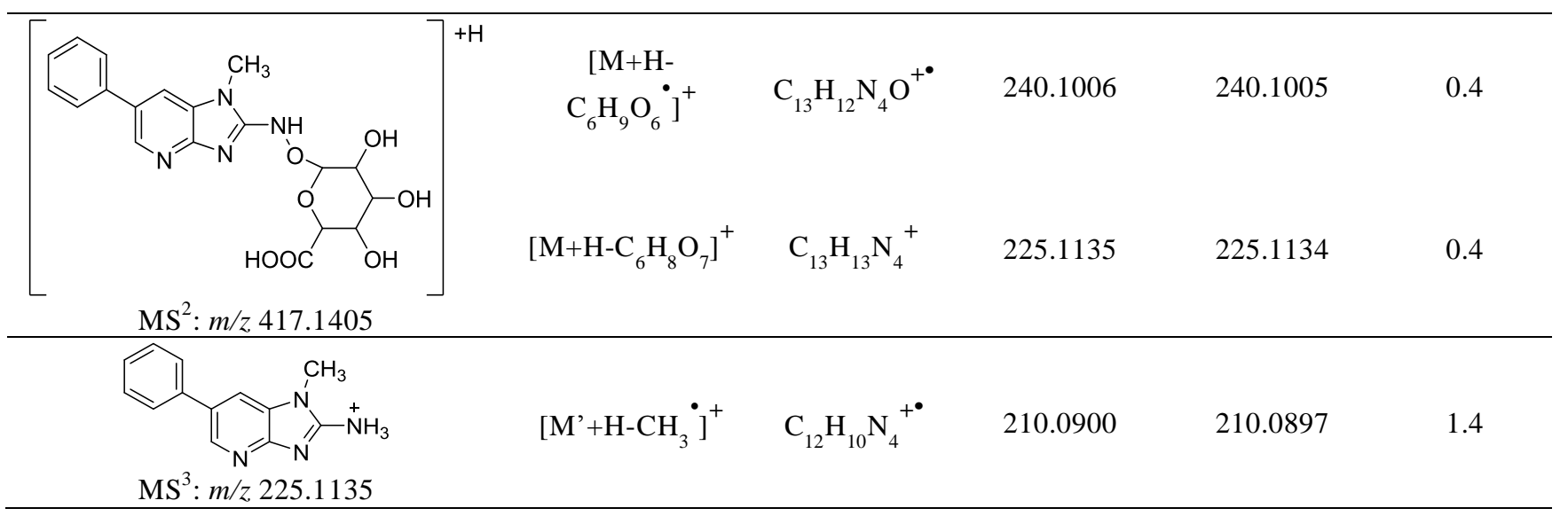


Table S-5. P450 Ethoxyresorufrin-O-deethylase (EROD) activities in human kidney and liver microsomes. ${ }^{a}$

\begin{tabular}{cccc}
\hline $\begin{array}{c}\text { Human kidney microsomes } \\
\text { (code) }\end{array}$ & $\begin{array}{c}\text { EROD assay } \\
\text { (pmol/min/mg protein) }\end{array}$ & $\begin{array}{c}\text { Human liver microsomes } \\
\text { (code) }\end{array}$ & $\begin{array}{c}\text { EROD assay } \\
\text { (pmol/min/mg protein) }\end{array}$ \\
\hline 649A & 1.31 & 129 & 12.80 \\
334A & 0.85 & 131 & 11.60 \\
234B & 0.71 & 133 & 24.15 \\
$766 \mathrm{~A}$ & 0.00 & 134 & 11.73 \\
$751 \mathrm{~A}$ & 1.51 & 135 & 41.96 \\
771A & 0.00 & 140 & 28.44 \\
\hline
\end{tabular}

${ }^{a}$ Average of triplicate independent measurements and values werer within $10 \%$ of each other. Limit of quantification was $0.5 \mathrm{pmol} / \mathrm{min} / \mathrm{mg}$ protein. 
A

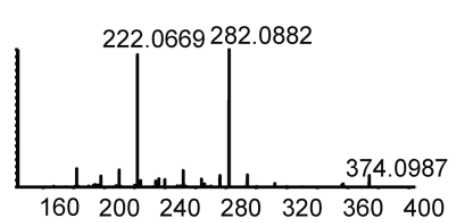

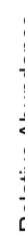

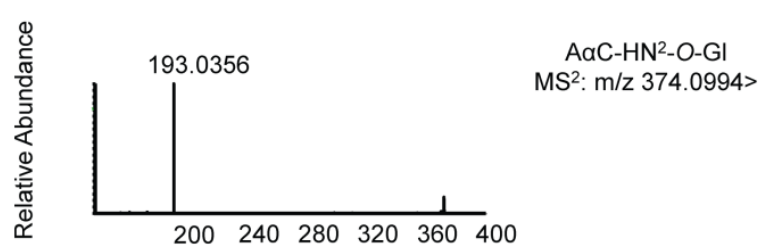

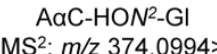

S/z 374.0994>

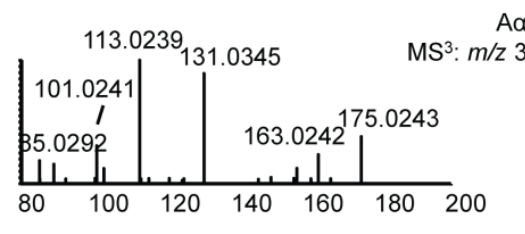

AaC-HN2-O-GI
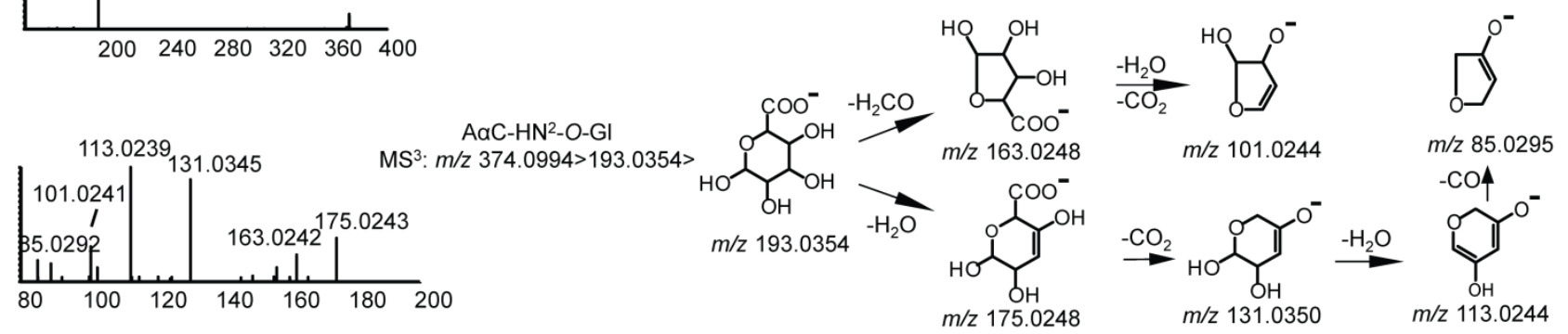

\section{B}

$\mathrm{AaC}-\mathrm{HON}^{2}-\mathrm{G}$

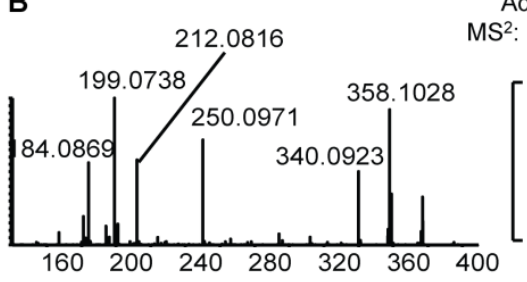

$\mathrm{MS}^{2}: \mathrm{m} / \mathrm{z}$ 376.1139>
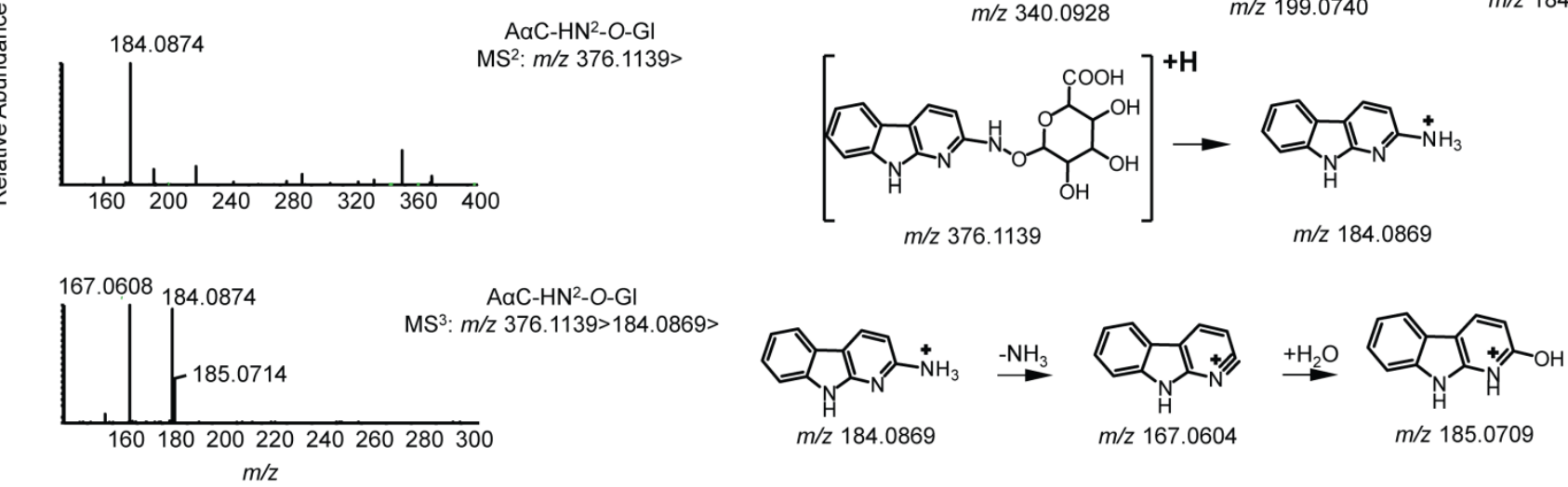

$\mathrm{m} / \mathrm{z} 167.0604$

Figure S-1. The high resolution mass spectra of Gluc conjugates of $\mathrm{HONH}-\mathrm{A \alpha C}$ in (A) negative ion mode and (B) positive ion mode. 

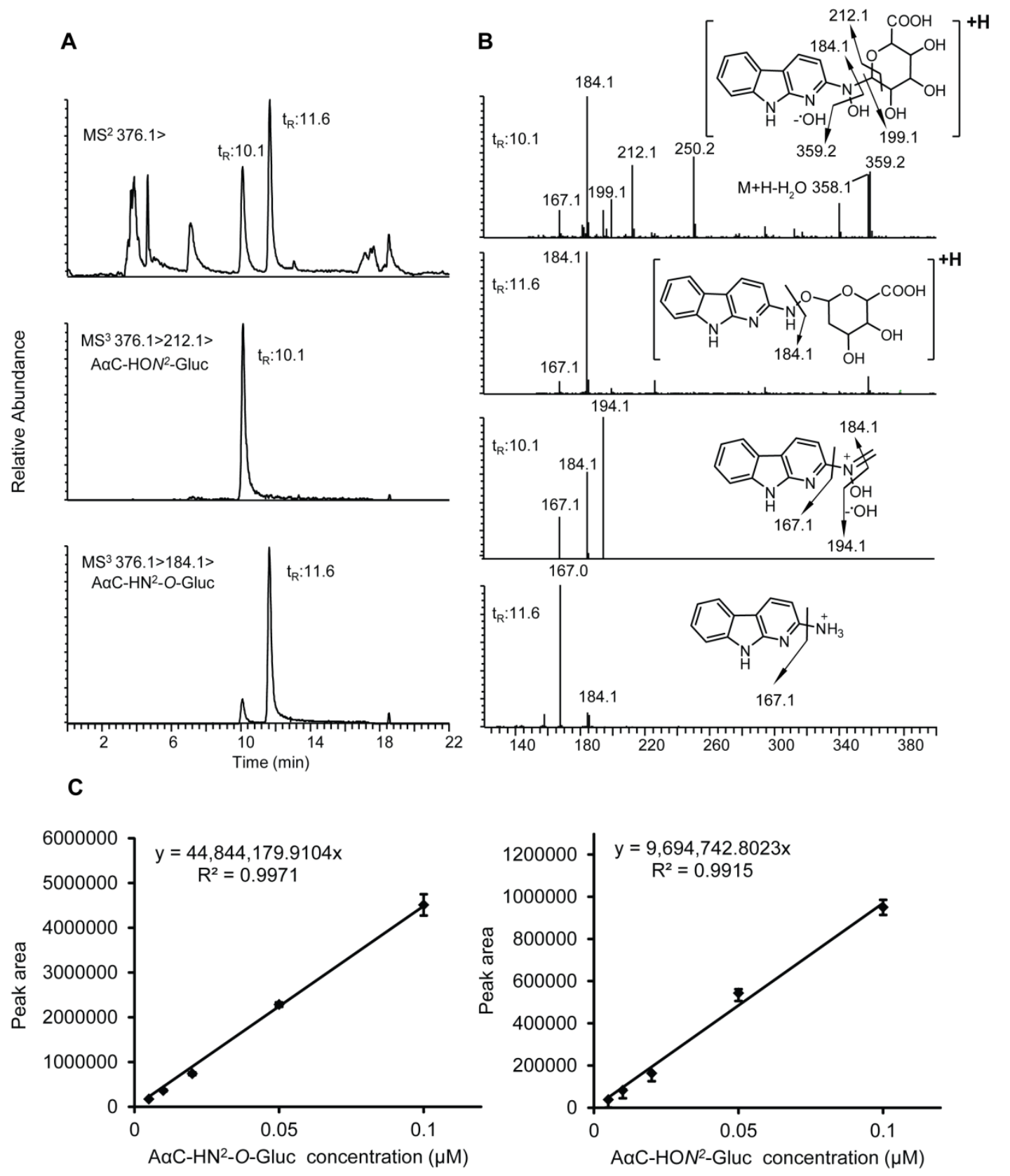

Figure S-2. A representative UPLC-ESI/MS ${ }^{2}$ and UPLC-ESI/MS ${ }^{3}$ chromatograms of Gluc metabolites of HONH-A $\alpha \mathrm{C}$ in human microsomes. A) HONH-A $\alpha \mathrm{C}-\mathrm{Gluc}$ metabolites formed with liver microsomes; B) The mass spectra of HONH-A $\alpha$ C-Gluc metabolites; C) Freshly prepared calibration curves of HONH-A $\alpha$ C-Gluc metabolites spiked into human liver microsomes $(0,0.005,0.01,0.02,0.05$, $0.1 \mu \mathrm{M})$ 

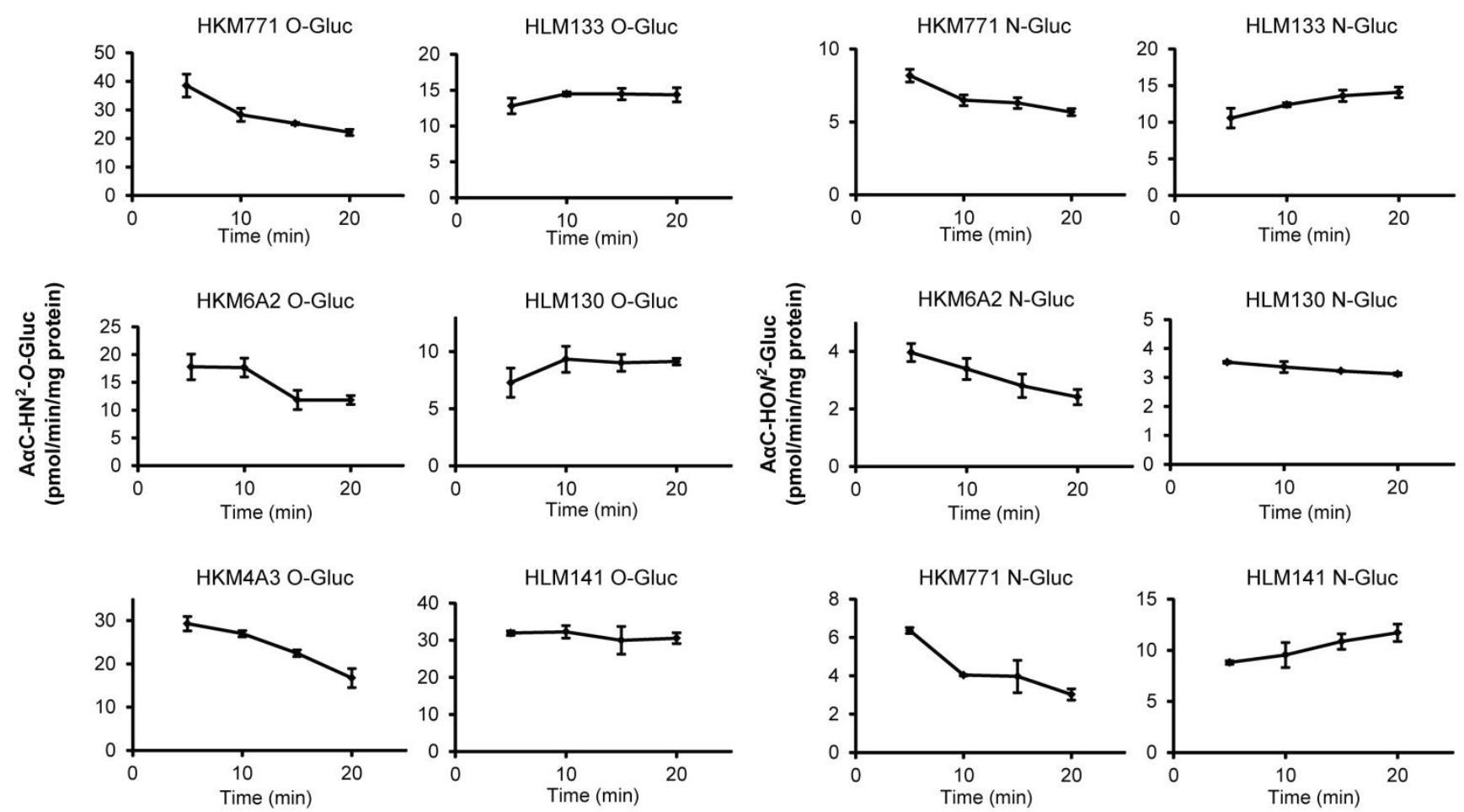

Figure S-3. The rates of formation of $\mathrm{HONH}-\mathrm{A} \alpha \mathrm{C}-\mathrm{Gluc}$ conjugates as a function of time with human kidney microsomes (HKM) and human liver microsomes (HLM). A) The rates of $\mathrm{A} \alpha \mathrm{C}-\mathrm{HN}^{2}-O-\mathrm{Gluc}$ formation; B) The rates of $\mathrm{A} \alpha \mathrm{C}-\mathrm{HO} N^{2}$-Gluc formation. 


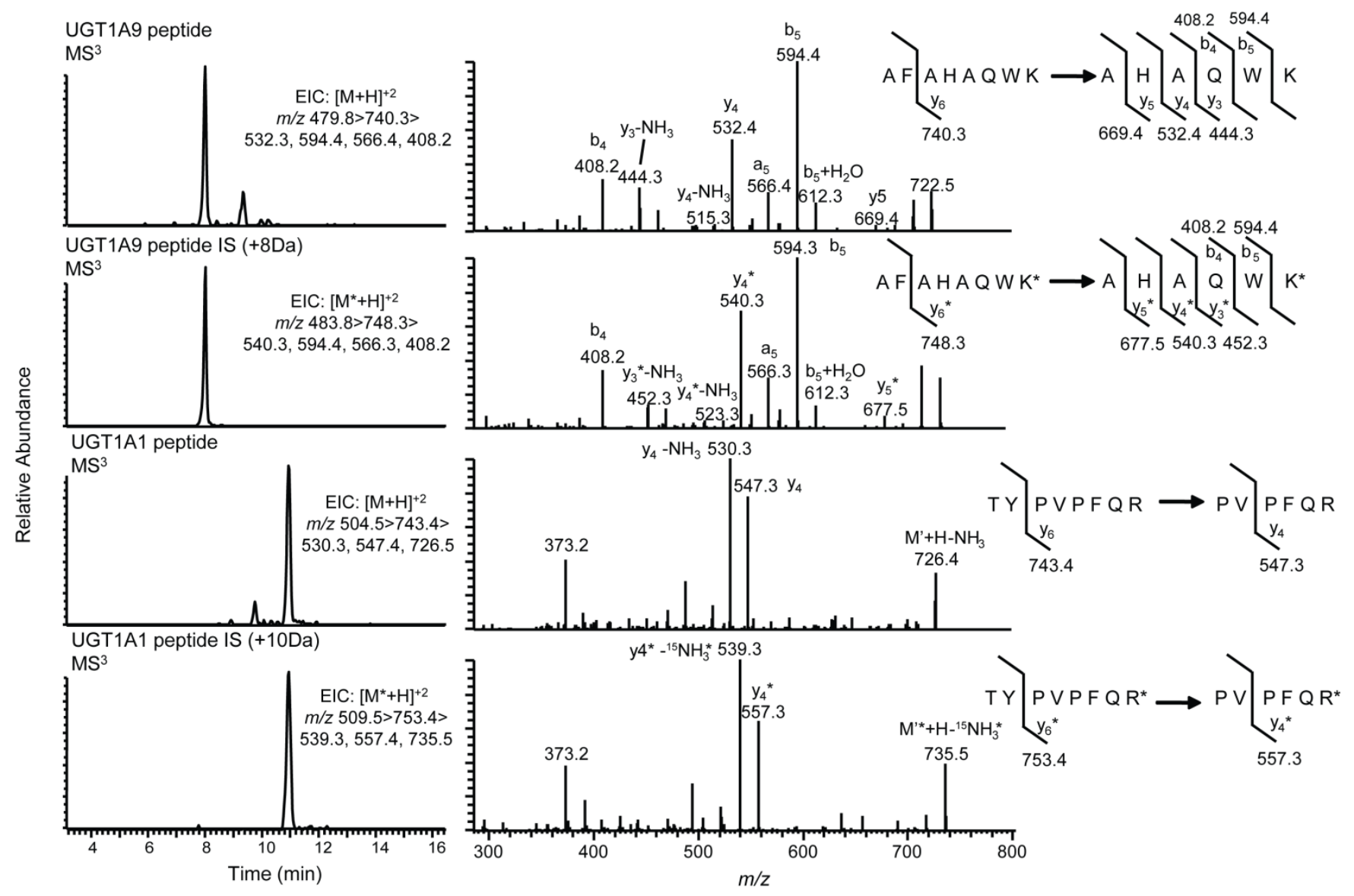

Figure S-4. The UPLC-ESI/MS ${ }^{3}$ chromatograms and mass spectra of unlabeled and labeled peptides of UGT1A1 and UGT1A9. 

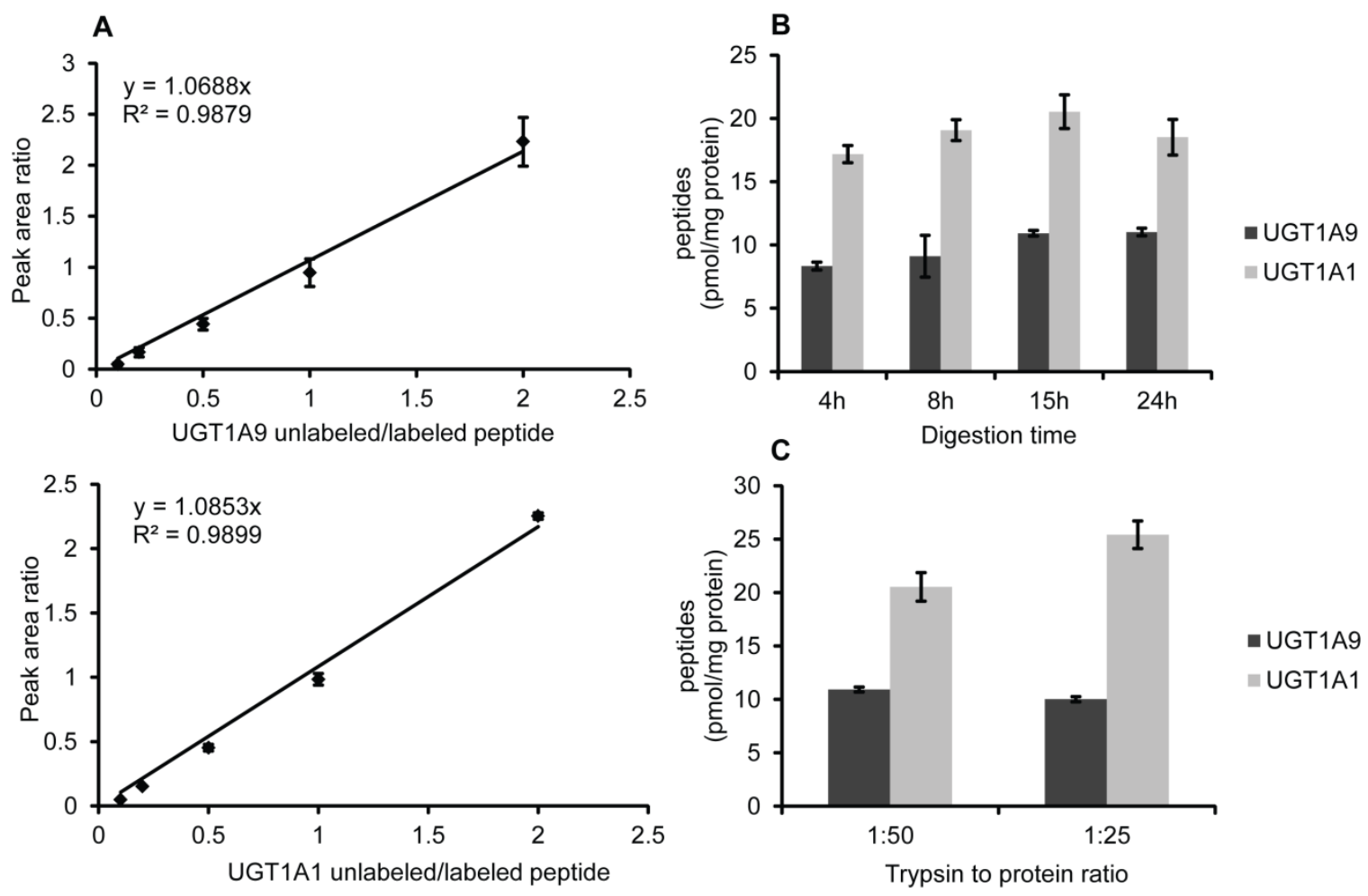

Figure S-5. Optimization of trypsin digestion. A) Calibration curves of UGT peptides (unlabeled peptides spiked into mouse liver microsomes with 1 pmol labeled peptides internal standards); B) Kinetics of UGT digestion with trypsin and recovery of $\mathrm{T}^{78} \mathrm{YPVPFQR}^{85}$ and $\mathrm{A}^{92} \mathrm{FAHAQWK}^{99}$; C) Comparison of different trypsin to protein ratios and recovery of peptides $\mathrm{T}^{78} \mathrm{YPVPFQR}^{85}$ and $\mathrm{A}^{92}$ FAHAQWK $^{99}$. 
S-14

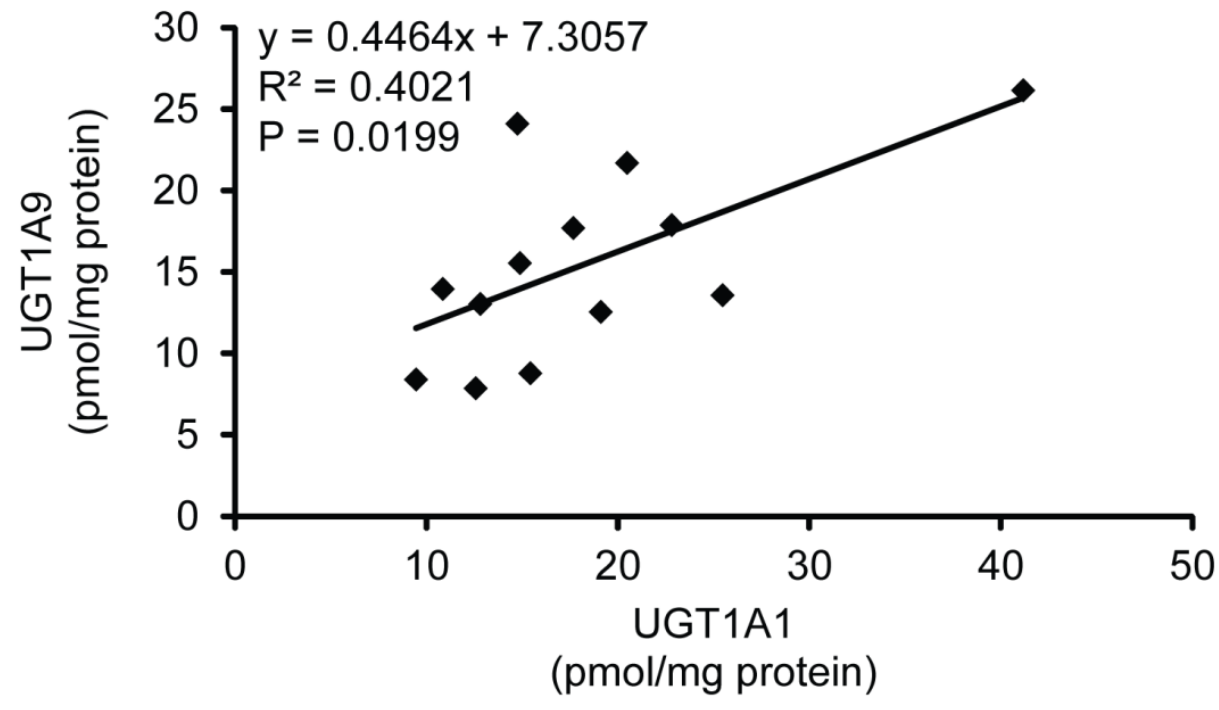

Figure S-6. The correlation between UGT1A1 and UGT1A9 protein expression levels in human liver microsomes. 
S-15
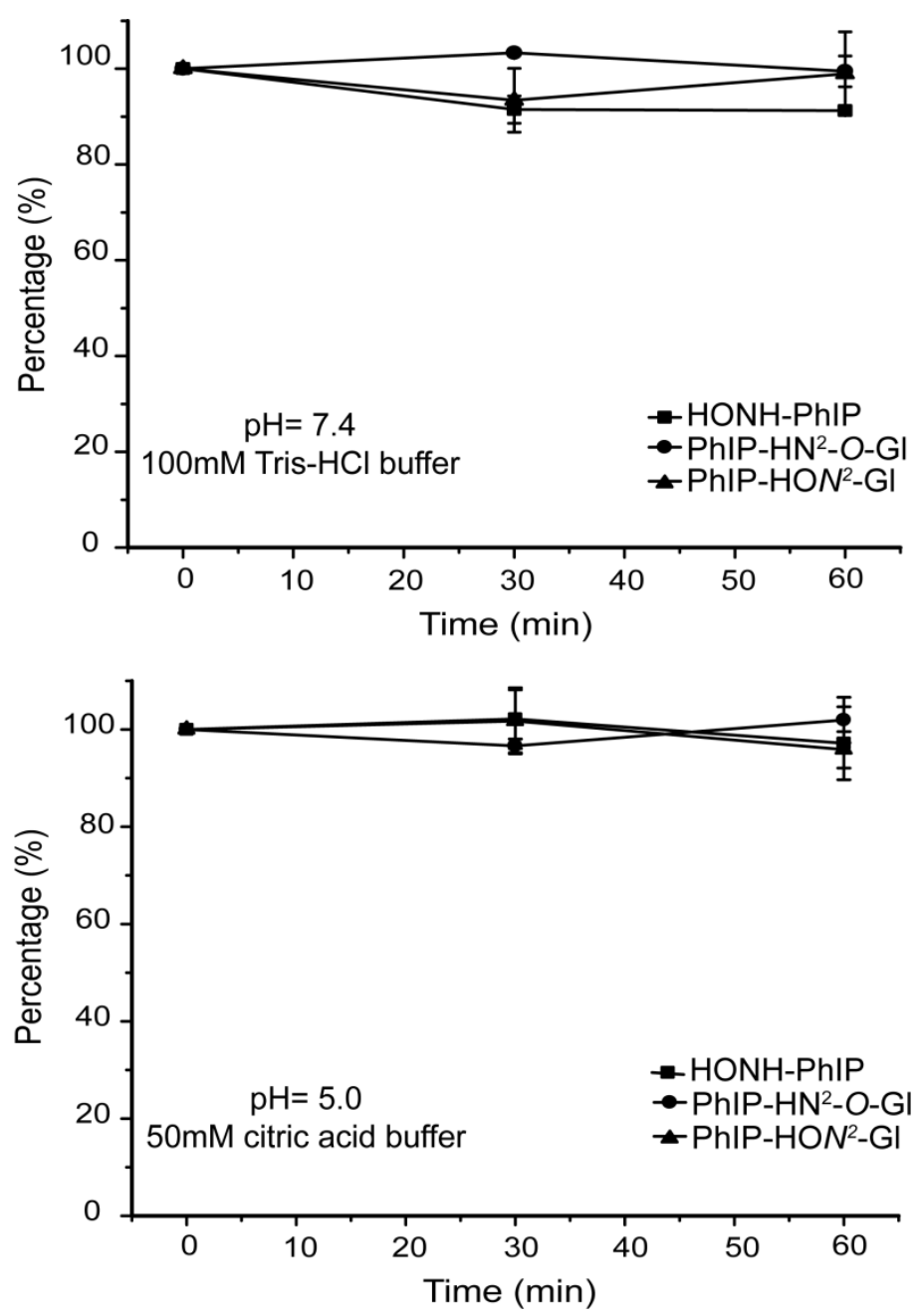

Figure S-7. The stability of HONH-PhIP and its Gluc conjugates as a function of $\mathrm{pH}$. 


\section{Reference}

(1) Tang, Y., LeMaster, D. M., Nauwelaers, G., Gu, D., Langouet, S., and Turesky, R. J. (2012) UDPGlucuronosyltransferase-mediated metabolic activation of the tobacco carcinogen 2 -amino-9Hpyrido[2,3-b]indole. J. Biol. Chem. 287, 14960-14972. 